2015

\title{
Expectant Fathers, Abortion, and Embryos
}

Dara Purvis

Penn State Law

Follow this and additional works at: http://elibrary.law.psu.edu/fac_works

Part of the Health Law and Policy Commons, and the Law and Gender Commons

\section{Recommended Citation}

Dara Purvis, Expectant Fathers, Abortion, and Embryos, 43 J.L. Med. \& Ethics 330 (2015).

This Article is brought to you for free and open access by the Faculty Works at Penn State Law eLibrary. It has been accepted for inclusion in Journal Articles by an authorized administrator of Penn State Law eLibrary. For more information, please contact ram6023@psu.edu. 


\section{Expectant Fathers,}

\section{Abortion, and Embryos}

\author{
Dara E. Purvis
}

oday, multiple legal theories of parenthood interact to encompass all sorts of families. Adults and children bound through adoption, step-parenting, and assisted reproductive technologies (ART) demand familial recognition through some combination of biology, functionality, technology, and intent.

In the context of children born through ART, many scholars have proposed a more robust use of intent as a rule for identifying legal parents. ${ }^{1}$ When used to identify parents, intent asks who planned to become the parent of a child, and is often helpful when multiple adults simultaneously agreed to bring a child into the world. For example, in the case of surrogacy, as many as five adults - two intended parents, a gestational surrogate, and both a sperm and egg donor could all contribute to bringing a single child into the world. Not only does intent provide a practical answer to such modern parentage dilemmas, but it recognizes the often-minimized emotional investment of men who wish to be fathers. ${ }^{2}$

When considering a man's intention to be a parent to a child not yet born, and whether the law can and should recognize his intent, the comparison to abortion is unavoidable. If the expectational parental interest of a man should be acknowledged in the context of a gestational surrogate pregnant with his intended child, should the expectational parental interest of a man whose wife is pregnant with his genetic progeny similarly be respected?

Analysis of the characterization of expectational parental interests of men shows the converse: rhetoric from abortion disputes reinforcing the gendered stereotype of men as uninvested in their expectational parental interests has seeped into the legal analysis employed in disputes in the context of ART. Courts faced with disagreements as to the use of stored preembryos are increasingly employing a balancing test that incorporates the gender stereotype in problematic ways.

Part I begins with abortion, describing how rhetoric in some abortion debates encourages a view of men as uninterested in fatherhood. Counterintuitively, the most dramatic examples come not from a pro-choice perspective, which could be caricatured as "my body, my choice" taken to a male-excluding extreme. Rather, anti-abortion portraits of women as blithely avoiding motherhood have given rise to an argument that men

Dara E. Purvis, J.D., M.Phil., is an assistant professor at Penn State Law. She received a J.D. from The Yale Law School, New Haven, Connecticut; an M.Phil. from the University of Cambridge, Cambridge, United Kingdom; and a B.A. from the University of Southern California, Los Angeles, California. 
must also be given a path to evade child support obligations. For both, the rhetoric of choice and a right not to be a parent is deployed to reinforce gender stereo- fessional lives. ${ }^{5}$ Descriptions of men as incapable on some level of grasping the significance of abortion and unwanted pregnancies is also an effective (and

\section{When considering a man's intention to be a parent to a child not yet born, and whether the law can and should recognize his intent, the comparison to abortion is unavoidable. If the expectational parental interest of a man should be acknowledged in the context of a gestational surrogate pregnant with his intended child, should the expectational parental interest of a man whose wife is pregnant with his genetic progeny similarly be respected?}

types. The expectational parental interest of women is all-consuming; the scale of maternal responsibilities and roles justifies why abortion is necessary for women to achieve equal rights. The expectational parental interest of men is a financial liability.

This framing of what the right not to be a parent means has had unintended consequences in the context of pre-embryo disputes, the subject of Part II. As courts have wrestled with how to evaluate disagreements regarding use of pre-embryos stored after in vitro fertilization (IVF) procedures, indeterminacy allows for the relative importance of male and female expectational parental interests to play a greater role in the court's analysis. Men have more power in the context of stored pre-embryos than anti-choice rhetoric discussed in Part I would expect, at least when their desire is not to develop a pre-embryo. As a general rule, modern courts have ruled that the right not to be a parent outweighs any right to procreate or expectational parental interest in the stored pre-embryos. Judges have acknowledged, however, a different balance when the stored pre-embryo may be the mother's last chance to be a genetic mother, finding that the circumstances overcome the right not to be a parent. ${ }^{3}$ The characterization of gendered expectational parental interests may thus influence the law in the context of ART in troubling ways.

\section{Part I. Abortion and Fathers}

For obvious reasons, abortion is often described as a women's issue. The characterization is understandable - only women undergo the abortion procedure or face the bodily impact of an unwanted pregnancy, and women generally shoulder the vast majority of the burdens of raising a child. ${ }^{4}$ Abortion has been framed as central to women's freedom and equality by feminist leaders, as controlling reproduction is crucial in giving women control over their personal and pro- humorous) political strategy, as when Gloria Steinem famously said, "If men could get pregnant, abortion would be a sacrament." 6

A closer examination of abortion jurisprudence and rhetoric reveals, however, that pro-choice advocates generally do not focus on abortion as a solely female concern, nor do they argue that men should be uninvolved in the discussion. In fact, both judges and commentators discussing abortion have explicitly acknowledged the "deep and proper concern and interest" of a potential father. ${ }^{7}$ Instead, the more common descriptions of abortion as excluding men entirely come from critics of abortion. Commentators paint a picture of men as powerless pawns who have no agency either to embrace or reject fatherhood, subject to the whims of pregnant women with the ability to terminate at will and deprive a man of fatherhood on the one hand, or to saddle him with a child support obligation on the other. Multiple commentators have argued that if a woman has a right not to be a parent embodied in her ability to terminate her pregnancy, a man should have a right not to be a parent by evading legal parentage and the attending child support obligation. ${ }^{8}$ Some anti-abortion rhetoric has shifted from mourning the expectational parental interest of joyful fathers to reinforcing a characterization of men as unwilling parents.

\section{Section A. Abortion Jurisprudence}

Courts wrestling with the right to privacy as it encompasses abortion have never entirely excluded men from the analysis - but neither have they regularly included men as central. In Roe v. Wade, the Court noted in a footnote that it need not "discuss the father's rights, if any exist in the constitutional context, in the abortion decision," as neither the statutes nor the lawyers on either side presented any claims of paternal rights. ${ }^{9}$ 
The Court thus identified as possible stakeholders the pregnant woman, the developing fetus, and the state.

It is worth noting, however, the Court's use of the word "father." Terminology in the context of abortion is often freighted with assumptions regarding moral status: fetus, child, or baby; mother or pregnant woman. What to call the man who believes he is the genetic father of the child, and who could later become the legal father of the child, is particularly vexing. In its own cases, the Court generally uses the word father, perhaps because none of the cases involve disputed future parental status. In later cases that involve genetic fathers seeking to be recognized father of the fetus, writing that " $[\mathrm{w}] \mathrm{e}$ are not unaware of the deep and proper concern and interest that a devoted and protective husband has in his wife's pregnancy and in the growth and development of the fetus she is carrying." ${ }^{14}$ This was not sufficient for dissenters such as Justice White, who read the law at issue as preventing a wife from "unilateral[ly]" terminating the husband's constitutional interest in the life of his putative child. ${ }^{15}$ Providing a frame of analysis that survives today, White wrote that in order not to give the husband a veto power over his wife's decision to terminate her pregnancy, the majority opinion weighed the interest of wife and husband in the potential life

\section{The Supreme Court's treatment of abortion thus leads to two interrelated conclusions as to the interests of expectational fathers. First, despite criticism the Court has never ignored or rejected male expectational parental interests altogether. Second, abortion decisions make clear that the pregnant woman's bodily autonomy is the dispositive concern in an abortion decision, and trumps any expectational father's claims.}

as legal fathers, the Court uses the phrase putative father. ${ }^{10}$ The phrase has been borrowed by scholars and sometimes used to refer to men who are believed to be the genetic father of a developing fetus. A hypothetical genetic connection to a child not yet born is more attenuated than the Court's use of putative father, however, and linguistically equating the two may elide an important distinction. For this reason, and to clearly identify the expectational interests in play, I will use the term expectational father.

Three years after Roe, in Planned Parenthood of Central Missouri v. Danforth, the Court addressed the expectational father's rights directly, striking down a law requiring that a married pregnant woman seeking to terminate her pregnancy secure the consent of her spouse. ${ }^{11}$ Statutes such as the law at issue in Danforth arose out of two competing strains of argument. On the one hand, one thread of opposition to abortion in the years after Roe directly challenged gender stereotypes and argued that expectational fathers must be included in the decision to terminate a pregnancy. ${ }^{12}$ On the other hand, practical applications of rules requiring male involvement in the decision increasingly focused on a husband's power over his wife rather than his interest in fatherhood. ${ }^{13}$

The Court's analysis in Danforth is notable for two reasons. First, Justice Blackmun's opinion for the Court gives explicit consideration to the expectational of their child and simply found that the wife's interest was more important. ${ }^{16}$ Justice White's criticism of the majority's balancing test was shared by Justice Stewart, whose concurrence similarly argued that the question of the husband's rights was "a rather more difficult problem than the Court acknowledges," even as he ultimately agreed with the Court's result. ${ }^{17}$ Both Justices argued that the majority did not sufficiently weigh the husband's interests, however, not that the Court ignored the expectational father altogether.

Second, the majority opinion ultimately rested its holding not on finding that expectant mothers held a greater interest in the potential life of a fetus, but rather in the pregnant woman's bodily autonomy. Blackmun's decision for the majority found that the balance was in the woman's favor because her status as the pregnant person gave her a dispositive personal stake, not because her status as potential mother was more important than the potential father. ${ }^{18}$ This reasoning implicitly rejected the expectational father's position, but not because his role or interest as a father was less valuable than the role or interest of a mother. Autonomy, rather than family roles, demanded that the decision whether to terminate a pregnancy rest solely with the pregnant woman.

This same logic reappeared when Pennsylvania attempted to evade the Court's holding by requiring mere spousal notification, rather than spousal 
consent. ${ }^{19}$ Again the Court recognized the "deep and proper concern and interest" of an expectational father, going even further to explicitly state that if the question were regarding actions taken with regard to "a living child raised by both," the interests of each parent would be equal. ${ }^{20}$ The woman's bodily autonomy was determinative and unrelated to any inchoate parental rights. The Court wrote:

Before birth,...the issue takes on a very different cast. It is an inescapable biological fact that state regulation with respect to the child a woman is carrying will have a far greater impact on the mother's liberty than on the father's. The effect of state regulation on a woman's protected liberty is doubly deserving of scrutiny in such a case, as the State has touched not only upon the private sphere of the family but upon the very bodily integrity of the pregnant woman..$^{21}$

The Supreme Court's treatment of abortion thus leads to two interrelated conclusions as to the interests of expectational fathers. First, despite criticism discussed in the next section, the Court has never ignored or rejected male expectational parental interests altogether. Second, abortion decisions make clear that the pregnant woman's bodily autonomy is the dispositive concern in an abortion decision, and trumps any expectational father's claims.

\section{Section B. Abortion Rhetoric}

Commentary, however, describes abortion law very differently. It is manifest that cherry-picking examples results in an extreme picture, but the characterizations of abortion laws and lawsuits are nonetheless striking. The Supreme Court has been described as "recognizing a woman's right to terminate her pregnancy, to be the master (or mistress) of her own procreative capabilities, [while] simultaneously trampl[ing] upon a man's right to be the master of his own procreative capabilities." ${ }^{22}$ Another pair of writers argued that women have despotic power over reproduction, as the dominant response to abortion is minimal, the dominant response to unwed motherhood is sympathy, and men are disadvantaged in addressing unplanned pregnancies as they have a single viable contraceptive choice. ${ }^{23}$

Such criticism points toward two paths of reform to ameliorate the gendered inequality of abortion law. One approach to equalizing the scale is to make it harder for women to terminate their pregnancies, giving an expectational father the ability to veto an abortion. Despite the clear precedent of Danforth and Casey, attempts are sporadically made to enact some form of male control over the abortion right. For example, in 2002, a man in Pennsylvania secured a court order prohibiting his ex-girlfriend - who had filed for a protection-from-abuse order against him - from terminating her pregnancy. The order was almost immediately overturned. ${ }^{24}$ In 2005 , an NYU professor published an op-ed in the New York Times arguing that " $[\mathrm{i}] \mathrm{f}$ a father is willing to legally commit to raising a child with no help from the mother he should be able to obtain an injunction against the abortion of the fetus he helped create," but immediately faced vehement public criticism. ${ }^{25}$ In the 2009 10 legislative session, about a dozen Ohio state legislators sponsored a bill that required a doctor to secure written informed consent from the father of a fetus before terminating a woman's pregnancy, making the first violation a misdemeanor and subsequent violations felonies. The bill, however, never progressed out of committee. ${ }^{26}$ While the Danforth strategy is revived every few years, it has been swiftly defeated each time.

The second response to a perceived sexism in the right to abortion turns away from abortion itself. Numerous advocates have instead proposed a different equalizing measure: because women have the legal option to terminate the pregnancy, men must be given a mirroring option to terminate their parental status. One author, comparing a woman terminating her pregnancy to Lorena Bobbitt cutting off her husband's penis, ${ }^{27}$ proposes that a pregnant woman be required to notify the expectational father of her pregnancy, at which point the expectational father may pay "appropriate fees" in order to obtain a "male abortion." 28 Another creative proposal argues that because abortion laws treat a fetus as akin to property rather than as a rights holding person, a man whose "property" has been terminated through abortion should be allowed to bring a conversion tort claim against the woman. ${ }^{29}$

Commentators also combine other elements of the laws regulating children and sexuality to bolster a portrayal of the American legal regime as systematically biased against men. The chief reference comparison is child support, arguing that although women may avoid parenthood by terminating pregnancy, men are unable to evade child support obligations even under extreme circumstances. To some extent, the criticism is correct - men are liable for child support in virtually all circumstances. Some of the most problematic cases arise from circumstances in which the man's consent to sexual activity is questionable at best. Consent can be difficult to prove, but extreme examples exist: for example, a case from Alabama almost two decades ago involved a woman who allegedly had sex with a man intoxicated to the point of passing out at a party, then later joked to friends about having been 
saved a trip to the sperm bank. ${ }^{30}$ In other instances, consent can be determined as a matter of law. Boys younger than 18 years old are legally unable to consent to intercourse, yet are routinely held liable for child support obligations, even where the biological mother is convicted and sent to jail for the sexual assault. ${ }^{31}$ Using such examples, multiple commentators argue that some weakening of the child support obligation is necessary to even out the right of a pregnant woman to terminate the pregnancy, usually through some mechanism by which a man voluntarily terminates his paternity. ${ }^{32}$

The argument is not merely a theoretical claim: litigants have argued the point in court as well, using the abortion frame to plead for relief from child support. In 2007, the National Center for Men (NCM) filed suit on behalf of Matt Dubay, who claimed that his girlfriend had assured him that she was infertile and that she was using birth control, thus tricking him into impregnating her. This notion of "contraceptive fraud," in which a man has sexual intercourse with a woman in reliance on her statement that she is taking birth control pills or otherwise taking steps to avoid pregnancy, has been unsuccessfully argued in a number of courts. ${ }^{33}$ The claims have been uniformly rejected on the grounds that the child's need for support is independent and unrelated to any alleged promises between the parents. ${ }^{34}$

The Dubay case, however, led with the comparison to the right to abortion. Labeling the case "Roe $v$. Wade for men," Dubay's attorneys argued that state law denied him equal protection of the law, as women could disavow parental status by terminating a pregnancy while men could not. ${ }^{35}$ Although Dubay was unsuccessful, he pursued his case to the Seventh Circuit, and the National Center for Men retains a link on its website sidebar to the apparently trademarked phrase "Roe v. Wade for men." ${ }^{6} 6$ The group appears to be eager for additional plaintiffs to bring similar claims, as Elle magazine published a story in 2013 about another man who was in contact with the NCM and preparing to sue before attempting to reconcile with the mother. ${ }^{37}$ Such arguments take the legal consequence of abortion - that the mother is "free" from obligations - and attempt to apply it to the narrow, financial view of male expectational parental interests. The significance of fatherhood is having to pay for the child's support; therefore, Roe v. Wade for men would free men's checkbooks. A proposed "right of refusal" of fathers is a refusal to fund. ${ }^{38}$

The gendered criticism of abortion has thus made strange bedfellows. Some of the initial proposals for "male abortions" terminating child support obligations seem to be modest proposals in the theme of
Jonathan Swift rather than genuine policy proposals. At least one article made the point explicit, noting "[l] est there be any confusion, this author is opposed, both legally and morally," to the line of cases establishing a constitutional right to privacy encompassing abortion, presenting her argument "as a reductio ad absurdum." ${ }^{2}$

This anti-abortion rhetorical argument, however, was taken at face value by groups such as the NCM, founded by a pro-choice man..$^{40}$ One unintended consequence of juxtaposing child support and abortion has thus been to take the focus away from the goal of ending the abortion right. Anti-abortion activists have implicitly acknowledged this by condemning the NCM's "Roe v. Wade for men" lawsuit, while still hoping that it would "expose the egregious error of the United States Supreme Court in making abortion a constitutional right." ${ }^{41}$

Another unintended consequence is more conceptual. Juxtaposing child support and abortion, however, focuses on a context in which challenges invariably arise because a man does not want to pay. Arguments over child support do not speak to the reasons abortion is important to women - that becoming a mother against her will "deprives a woman of the right to make her own decision about reproduction and family planning - critical life choices [that have] a dramatic impact on a woman's educational prospects, employment opportunities, and self-determination." 42 By turning from narratives of men saddened by abortion, who had hoped to become fathers, and focusing on unwilling fathers whose parental investment was limited to sending checks, abortion critics reinforced the perception of men as uninvested in children, a perception they initially criticized. As the next section discusses, this rejection of the male expectational parental interest has unintended consequences in the context of ART.

\section{Part II. ART, Pre-embryos, and Expectational Parental Interests}

As the Supreme Court has reasoned, the bodily autonomy of a pregnant woman outweighs any expectational parental interests in the context of the abortion decision. Disagreements regarding what to do with stored pre-embryos, however, remove bodily autonomy from consideration, as by definition the pre-embryos are not yet implanted in a woman. Pre-embryo disputes thus pit the potential parents' expectational interests against each other on a level playing field, ${ }^{43}$ offering what Carol Sanger has described as "about as close as we may presently come to approximating an abortion decision for men." ${ }^{44}$ 
Although courts disagree as to how to resolve disagreements over pre-embryos, it is apparent that the stereotypes underscored in the abortion debates are doing some work. Men are expected to typically be reluctant parents, and it is accurate that the majority of reported pre-embryo arguments feature the male as the person wishing not to implant the pre-embryos. In addition to this, however, courts and commentators have repeatedly expressed special sympathy for the expectational interests of women who wish to become parents. When faced with dilemmas turning on expectational parental interests, courts have a tendency to revert to stereotypes about gendered parental roles: men are concerned with the cost of a child, whereas women yearn for the emotional connection with a baby. Cases such as pre-embryo disputes raise hard questions without clear answers - and in that void, stereotypes regarding stronger female expectational parental interests have begun to play an increasingly determinative, and increasingly problematic, role.

\section{Section A. Disputes over Pre-embryos}

When assisted reproductive technologies such as IVF are used to generate a pregnancy, male and female gametes are combined in a fertility clinic laboratory, developed into an eight-cell pre-embryo, ${ }^{45}$ and cryogenically frozen. ${ }^{46}$ Some pre-embryos are transferred into a woman's uterus in the hopes that at least one develops into a viable pregnancy, but because not all pre-embryos successfully implant and not every implantation attempt results in a full-term pregnancy, the clinic will produce a number of pre-embryos and store them. Furthermore, many people using IVF will ultimately hope to have more than one child, so clinics often store pre-embryos for years to reserve the possibility that the parent or parents may use additional pre-embryos for a younger sibling.

In the intervening years, however, the genetic mother and father of the pre-embryo may no longer agree whether they wish to have more children, or whether they wish the pre-embryos to be destroyed or donated to another couple. These disputes are particularly common where the parents have divorced.

Fertility clinics generally require that clients complete a form agreement specifying what will be done with the pre-embryos, sometimes specifying what will be done in the event that the intended parents divorce. A number of courts will enforce the parties' future intent as specified in the agreement, an approach that has come to be labeled the contractual model. Using the contractual model, courts presume that agreements signed in advance of the creation of pre-embryos are binding, and will enforce them so long as the agreement covers the circumstances of the case. ${ }^{47}$ In one of the earliest examples of the contractual model, the New York Court of Appeals explained that enforcing agreements using traditional principles of contract law is predictable, reasonably certain, and encourages couples to take seriously the obligations of using IVF rather than engaging in expensive and time-consuming litigation after disputes arise. ${ }^{48}$ In virtually all cases, a contractual approach resulted in destruction of the pre-embryos. ${ }^{49}$ In an Oregon case from 2008 , the court explicitly rejected the male progenitors argument that "his desire to preserve what he believes to be life should be considered more important than wife's desire to avoid having a child born from one of her eggs." 50

The least common mode of analysis is known as contemporaneous mutual consent, requiring that both intended parents agree as to disposition of the pre-embryos in order for any action to be taken, even if the reason for disagreement is that one person changed his or her mind from their previous intent as expressed in a written agreement. ${ }^{51}$ For obvious reasons, this approach will tend to result in the preembryos being stored indefinitely, and likely destroyed as soon as the person wishing to use the pre-embryos is no longer willing to pay storage fees to the fertility clinic. Although some commentators support use of the contemporaneous mutual consent approach, ${ }^{52}$ it has been strongly criticized for giving one ex-spouse a powerful bargaining point at a time when conflict between the ex-spouses is volatile. ${ }^{53}$ Perhaps because of this weakness, only Iowa has formally adopted the approach. ${ }^{54}$

The final method, known as the balancing approach, is the most likely to give voice to gendered parental stereotypes, and thus the most problematic. The approach was first articulated in the Tennessee State Supreme Court in 1992, after a contentious battle through lower courts. The facts are typical for preembryo disputes: Junior and Mary Sue Davis underwent IVF while their marriage was intact. After their marriage ended, Mary Sue wanted to attempt to bring the pre-embryos to term, whereas Junior did not. At the first stage of litigation, the Tennessee Circuit Court found that the pre-embryos were persons, and awarded "custody" of the pre-embryos to Mary Sue. ${ }^{55}$ The Tennessee Court of Appeals reversed, rejecting the lower court's personhood conclusion and finding that allowing implantation of pre-embryos against one intended parent's will would violate that person's constitutional right "not to beget a child where no pregnancy has taken place. ${ }^{56}$

The state supreme court noted that the Davises had not signed a written agreement expressing their wishes in the event of divorce, and therefore contractual 
readings provided no solution.$^{57}$ In order to resolve the dispute, the court turned to balancing the interests of each party. ${ }^{58}$ On the one hand, Junior argued that due to his own history as a child of divorce, he did not want to bring children into an already-broken marriage. By contrast, Mary Sue did not want the pain and effort of creating the pre-embryos to go to waste - notably, as of the first appeal, Mary Sue no longer wished to husband could not father children of his own. ${ }^{62}$ The state supreme court concluded that typically, the result would be in favor of the party seeking not to become a biological parent. ${ }^{63}$

Recent applications of a balancing approach, however, highlight how gendered stereotypes regarding expectational parental interests may come to have a larger role in evaluations of pre-embryo disputes. In a

\section{Despite the neat tripartite division, most courts - with the notable exception of Iowa - seem to be moving towards Szafranski’s standard: enforce agreements providing for the disposition of pre-embryos where possible, and in the absence of an agreement addressing the circumstances at hand, balance the interests of the parties. Even jurisdictions that adopted the contractual approach have occasionally provided caveats, such as noting that agreements might be unenforceable if the circumstances underlying the agreement had significantly changed.}

develop and raise the pre-embryos herself, but wished to donate them to other couples. ${ }^{59}$ This court noted that "[t]he case would be closer if Mary Sue Davis were seeking to use the pre-embryos herself, but only if she could not achieve parenthood by any other reasonable means." 60 The court then established a general rule of balancing. In the absence of a written agreement establishing the intent of the parties,

Ordinarily, the party wishing to avoid procreation should prevail, assuming that the other party has a reasonable possibility of achieving parenthood by means other than use of the preembryos in question. If no other reasonable alternatives exist, then the argument in favor of using the preembryos to achieve pregnancy should be considered. However, if the party seeking control of the preembryos intends merely to donate them to another couple, the objecting party obviously has the greater interest and should prevail. ${ }^{61}$

Other courts using the balancing test have adopted a similar structure: typically the right not to be a parent outweighs the right to be a parent, unless the party seeking to become a parent through development of the pre-embryos cannot do so by any other means. In a New Jersey case in which the ex-husband sought to donate the pre-embryos to other couples against the wishes of his ex-wife who wanted the pre-embryos destroyed, the dispute was described as "more apparent than real" by the court, as there was no reason the
2012 Pennsylvania case, the pre-embryos were created after the ex-wife was diagnosed with breast cancer. Knowing that her cancer treatment would likely leave her infertile, she went through IVF before undergoing surgeries, chemotherapy, and radiation treatment. ${ }^{64}$ The Pennsylvania Superior Court noted as "a compelling circumstance" that the trial court found that the ex-wife was unable to bear biological children after her cancer treatments. ${ }^{65}$ The court ultimately determined that "these pre-embryos are likely Wife's only opportunity to achieve biological parenthood and her best chance to achieve parenthood at all," and thus she should be allowed to proceed with implantation over the objections of her ex-husband. ${ }^{66}$

Reber was cited in Szafranski v. Dunston, a 2013 Illinois case with similar facts, in which the intended mother sought IVF after she was diagnosed with nonHodgkin's lymphoma and told that treatment would likely render her infertile. ${ }^{67}$ Interestingly, her ex-partner explicitly framed his argument through the lens of abortion, arguing that because the intended father and mother are in equal positions when it comes to cryopreserved pre-embryos, his constitutional right not to be a parent should trump the intended mother's desire to use the pre-embryos. ${ }^{68}$ By contrast, the intended mother argued that Reber's balancing test weighing her fertility options should be used. ${ }^{69}$ The court adopted the contractual approach, but found that in the absence of an agreement expressing the intent of the intended parents, Reber's balancing approach should be used, and remanded the case for further fact finding as to whether the intended father had con- 
sented to an agreement giving the intended mother sole decision making power over the pre-embryos..$^{70}$

\section{Section B. Expectational Parental Interests and the Balancing Test}

Despite the neat tripartite division, most courts - with the notable exception of Iowa - seem to be moving towards Szafranski's standard: enforce agreements providing for the disposition of pre-embryos where possible, and in the absence of an agreement addressing the circumstances at hand, balance the interests of the parties. Even jurisdictions that adopted the contractual approach have occasionally provided caveats, such as noting that agreements might be unenforceable if the circumstances underlying the agreement had significantly changed..$^{71}$

In practice, as multiple courts have acknowledged, this will mean that most of the time the party seeking not to become a parent will prevail. ${ }^{2}$ Glenn Cohen has suggested this approach, with the caveat that perhaps the default should allow for exceptions where one of the potential parents will otherwise be unable to have biological children..$^{73}$

Thus far, examples of parents for whom frozen preembryos are a last chance have been clear-cut, as in the woman who underwent IVF before beginning cancer treatment. Diagnosed infertility provides an unambiguous justification of why one person's expectational parental interests might be heightened. But what if the expectational parents suffered from unexplained infertility, such that a doctor recommended that they try IVF without having a clear explanation as to what was causing fertility problems or in which person the issue arose? Any time that IVF is utilized and pre-embryos are stored, one or both expectational parents will have some characteristic that led them to seek out ART, such as infertility, a same-sex partnership, or a desire to screen out potential genetic issues. Any expectational parent litigating over stored preembryos thus has some foundation to argue that his or her expectational interests are magnified.

Given perceptions of women as more desperate to become parents ${ }^{74}$ and more vulnerable to a ticking biological clock, it is clear that women may find it easier to articulate strong expectational parental interests. Requiring certain and explainable infertility before finding that the right to be a parent outweighs the right not to be a parent is clear, but impractical. Yet once the door is opened, and a court recognizes heightened expectational parental interests of a person whose inability to bear a child without utilizing stored pre-embryos is a possibility of less than one hundred percent, the argument could become a slippery slope. Overheated social narratives of women's dwindling fertility as they age, for example, could have immense effect upon a judge weighing whether a preembryo is in fact an older single woman's last chance to become a mother, particularly when the woman has spent additional years of her life litigating the case..$^{75}$

Courts have already expressed sympathy for the emotional and physical difficulties of undergoing IVF. The Davis v. Davis trial court found it was "undisputed in the record...[that] Mrs. Davis went through many painful, physically tiring, emotionally and mentally taxing procedures." 76 The appellate court memorably termed this the "sweat equity model." 77 The Reber $v$. Reiss court further stressed the importance of the sweat equity of pregnancy:

Adoption is a laudable, wonderful, and fulfilling experience for those wishing to experience parenthood, but there is no question that it occupies a different place for a woman than the opportunity to be pregnant and/or have a biological child. As a matter of science, traditional adoption does not provide a woman with the opportunity to be pregnant. 78

The developing trend of a balancing approach, in other words, has thus far reinforced a general sense that the right not to be a parent - the male negative expectational parental interest - outweighs a claim to be a parent. In this sense, this means that men have more power than the rhetoric discussed in Part I might suggest.

This only holds true, however, so long as the party wishing to become a parent has reasonable opportunities to become a genetic parent. In the case of a woman, this may mean not only a reasonable opportunity to become a genetic parent, but also to be pregnant herself. Given popular perceptions regarding male and female reproductive capacities through old age, courts could be swayed by arguments that frozen pre-embryos represent a woman's last chance.

Expectational parental interests, in other words, could become further tied to female desires, female reproductive capacity, and the (female) ability to become pregnant. Not only does this underscore a perception that men have no stake in parenthood either because they generally do not want to become fathers or because they simply have the opportunity to become fathers until late in life - but it further casts expectational parental interests as more important to women.

Thus far, this may be an accident of circumstance, in that the only intended parents bringing lawsuits seeking to use stored pre-embryos after they were rendered infertile have been female. It seems likely 
that in such an extreme circumstance, a male plaintiff would be similarly successful in bringing a Reber claim that the pre-embryos were his only chance to be a genetic father. Expectational parental interests, in other words, are not held solely by women.

Women do, however, have more arguments for the significance of their expectational parental interest. The female expectational parental interest encompasses the significance of pregnancy in addition to becoming a genetic parent. Women's reproductive capacity means that by definition, their future chances at becoming a genetic parent shrink as time ticks on, in contrast to a man's. Both men and women's expectational parental interests likely win the balancing test if it is demonstrably and objectively their last chance at genetic parenthood - but only women can argue that there is also a gray area when it may be their last chance at genetic parenthood or pregnancy. In the narrow context of disputes over stored pre-embryos, this gray area is not necessarily problematic. As the conclusion discusses, however, the unintended consequences of conceptualizing expectational parental interests as more important to women may stretch beyond such rare cases.

\section{Conclusion: Beyond Embryos}

The confluence of abortion and frozen pre-embryo rhetoric operating to minimize male expectational parental interests may appear to have relatively narrow legal impact at first impression. Casting expectational parental interests as exclusively female, however, has several broader consequences.

One is the corollary to an expectational parental interest - expectational parental obligations. As discussed in Part I, the expectational parental interest of men has been described by some activists as solely financial. By contrast, courts acknowledging the sweat equity of IVF discuss the physically, emotionally, and mentally taxing experiences that women take on in their pursuit of the further burdens of pregnancy. This reinforces existing stereotypes that women are more natural parents than men. A robust reading of the stereotype moves from what women are more naturally inclined to do to what women should do. Women are accordingly further burdened by the expectation that they can, should, and must do whatever possible to bring an optimal pregnancy to term.

There have been dramatic examples from the last few decades of women facing extreme legal burdens as the result of pregnancy: forced caesarian sections in order to save the developing fetus ${ }^{79}$ or even criminal liability. ${ }^{80}$ In January 2014, a Texas hospital enforced a statute forbidding withdrawing life-sustaining treatment from a pregnant patient to prohibit them from taking a brain-dead pregnant woman off of a ventilator, even where her husband and parents agreed that her wishes had been not to be kept on life support in that state. ${ }^{81}$ Stereotyped expectational parental interests reach not only the strength of the desire of men and women to become a parent, but the conduct that is appropriate when trying to become a parent. Assuming that a woman deeply wants to become a mother extends to assuming that a woman will conform to societal expectations of what she should do or who she should be as a potential mother.

The gendered characterization of expectational parental interests also bears upon every nontraditional family. Minimizing the interests of the nonpregnant parent cuts off a whole host of parents - men, same-sex partners, adoptive parents, and so on. Opponents of marriage equality in California argued that same-sex parents cannot "unite the biological, social and legal components of parenthood into one lasting bond." 82

The confluence of abortion and pre-embryo dispute rhetoric, in other words, works to minimize nonpregnant expectational parental interests, rather than simply a man's desire to be a father. In order to avoid this result, commentators and courts should be careful to frame each question. In the context of abortion, the bodily autonomy of the pregnant woman should be at the forefront of analysis, while explicitly acknowledging that this necessarily trumps sympathetic expectational interests. In the context of pre-embryo disputes and other ART circumstances, advocates of a balancing test must be careful in characterizing the interests of potential parents. Whenever possible, the exigencies of an individual circumstance should not be extrapolated to limit the rights of entire genders. Inability to become a genetic parent should be distinguished from lowered probabilities of becoming a genetic parent, and the experience of pregnancy must be separated from parenthood more generally.

\section{Acknowledgments}

Grateful thanks for the thoughtful comments of Wendy A. Bach, Dawn Johnsen, Adam Muchmore, Victor Romero, and Justin Weinstein-Tull.

\section{References}

1. See, e.g., D. E. Purvis, "Intended Parents and the Problem of Perspective," Yale Journal of Law \& Feminism 24, no. 2 (2012): 210-253.

2. See D. E. Purvis, "The Origin of Parental Rights: Labor, Intent, and Fathers," Florida State University Law Review 41, no. 3 (2014): 645-696.

3. See Reber v. Reiss, 42 A.3d 1131 (Pa. Super. 2012), discussed infra Section II.A.

4. A. R. Hochschild and A. Machung, The Second Shift (New York: Penguin Books, 2003): at 4; L. Sanchez and E. Thom- 
son, "Becoming Mothers and Fathers: Parenthood, Gender, and the Division of Labor," Gender and Society 11, no. 6 (1997): $747-772$, at 765 .

5. See L. Greenhouse and R. B. Siegel, "Before (and After) Roe v. Wade: New Questions About Backlash," Yale Law Journal 120, no. 8 (2011): 2028-287, at 2042-243; see also M. Ziegler, "Abortion and the Constitutional Right (Not) to Procreate," University of Richmond Law Review 48, no. 4 (2014): 12631317, at 1278 (quoting Jan Liebman of the National Organization for Women arguing, "The woman is the one who carries the fetus, and gives birth to it, so she should be the only one to decide whether to carry it to term").

6. G. Steinem, "The Verbal Karate of Florynce R. Kennedy, Esq.," Ms. Magazine, March 1973 (quoting Florynce Kennedy), available at <http://www.msmagazine.com/summer2011/verbalkarate.asp> (last visited April 14, 2015).

7. Planned Parenthood of Cent. Mo. v. Danforth, 428 U.S. 52, 69 (1976).

8. See, e.g., C. Bruno, " A Right to Decide Not to Be a Legal Father: Gonzales v. Carhart and the Acceptance of Emotional Harm as a Constitutionally Protected Interest," George Washington Law Review 77, no. 1 (2008): 141-171.

9. Roe v. Wade, 410 U.S. 113 , 165 n.67 (1973).

10. See, e.g., Lehr v. Robertson, 463 U.S. 248 (1983); Parham v. Hughes, 441 U.S. 347 (1979); Caban v. Mohammed, 441 U.S. 380 (1979); Stanley v. Illinois, 405 U.S.645 (1972).

11. Danforth, 428 U.S. at 58.

12. See Ziegler, supra note 5, at 1277.

13. Id., at 1290 .

14. Danforth, 428 U.S. at 69.

15. Id., at 93 (White, J., dissenting)

16. $I d$.

17. Id., at 90-91 (Stewart, J., concurring).

18. Id., at 71 .

19. See Planned Parenthood of Se. Pa. v. Casey, 505 U.S. 833 (1992).

20. Id., at $895-896$. The phrase "a living child raised by both" is important, as unwed biological fathers lack a constitutional interest in their child until they create a substantial relationship with the child. See Purvis, supra note 2. If the biological father is not involved in raising the child, in other words, he lacks a cognizable constitutional interest in a relationship with the child.

21. Id., at 896

22. E. M. Hiester, "Child Support Statutes and the Father's Right Not to Procreate," Ave Maria Law Review 2 (2004): 213-241, at 214-215.

23. See I. D. Lichtenberg and J. B. LeClair, "Advocating Equal Protection for Men in Reproductive Rights and Responsibilities," Southern University Law Review 38, no. 1 (2010): 53-78, at 63.

24. Even further court battles were mooted when the woman miscarried. See J. Roberts, "Ex-Boyfriend Cant' Stop Abortion," CBSNews.com, available at <http://www.cbsnews.com/ news/ex-boyfriend-cant-stop-abortion/> (last visited April 14, 2015); see also D. Lithwick, "Dad's Sad, Mad: Too Bad," Slate, August 7, 2002, available at <http://www.slate.com/articles/ news_and_politics/jurisprudence/2002/08/dads_sad_mad_ too bad.html $>$ (last visited April 14, 2015).

25. D. Conley, Op-Ed, "A Man's Right to Choose," Nerw York Times, December 1, 2005, available at <http://www.nytimes. com/2005/12/01/opinion/01conley.html> (last visited April $14,2015)$.

26. H.B. 252, 2009 Leg., 128th Sess. (Oh. 2009), available at $<$ http://archives.legislature.state.oh.us/bills.cfm?ID $=128$ HB_252> (last visited April 24, 2015).

27. See M. A. Totz, "What's Good for the Goose Is Good for the Gander: Toward Recognition of Men's Reproductive Rights," Northern Illinois University Law Review 15, no. 1 (1994): 141236 , at $142-143$.

28. Id., at 177 .
29. See M. R. Pahl, "It Takes Two, Baby: Fathers, the Tort of Conversion, and Its Application to the Abortion of Pre-Viability Fetuses," Whittier Law Review 24, no. 1 (2002): 221-251.

30. See S.F. v. State ex rel. T.M., 695 So. 2d 1186, 1187 (Ala. Civ App. 1996); see also State v. Frisard, 694 So. 2d 1032, 1035 (La. Ct. App. 1997) (alleging that a woman saved semen in a condom after oral sex and used it to impregnate herself).

31. See R. Jones, "Inequality from Gender-Neutral Laws: Why Must Male Victims of Statutory Rape Pay Child Support for Children Resulting from their Victimization?” Georgia Law Review 36, no. 1 (2002): 411-463, at 432-443.

32. See, e.g., C. Bruno, "A Right to Decide Not to be a Legal Father: Gonzales v. Carhart and the Acceptance of Emotional Harm as a Constitutionally Protected Interest," George Washington Law Review 77, no. 1 (2008): 141-171; M. G. McCulley, "The Male Abortion: The Putative Father's Right to Terminate His Interests In and Obligations to the Unborn Child," Journal of Law E Policy 7, no. 1 (1998): 1-55 (proposing a model statute allowing putative fathers to terminate parental status for several reasons, including that the putative father offered to pay for an abortion); E. M. Hiester, "Child Support Statutes and the Father's Right Not to Procreate," Ave Maria Law Review 2 (2004): 213-241, at 239-240 (proposing model statute giving biological father the ability to terminate parental status for as long as the biological mother would have access to legal abortion)

33. See, e.g., Wallis v. Smith, 22 P.3d 683 (N.M. App. 2001); Welzenbach v. Powers, 660 A.2d 1133 (N.H. 1995); Stephen K. v. Roni L., 164 Cal. Rptr. 618 (Ct. App. 1980).

34. See Wallis, 22 P.3d at 685; Stephen K, 164 Cal. Rptr. at 621 (adding that even had defendant been taking birth control pills, the rate of pregnancy prevention of birth control pills is less than $100 \%$ ).

35. Dubay v. Wells, 506 F.3d 422, 426-8 (6th Cir. 2007).

36. The National Center for Men, available at <http://www. nationalcenterformen.org/index.shtml> (last visited April 14, 2015).

37. S. Fairyington, "The Parent Trap: Paternal Rights and Abortion," Elle, March 17, 2013, available at <http://www.elle.com/ life-love/society-career/the-parent-trap-paternal-rights-abortion-445117> (last visited April 14, 2015).

38. S. D. Hales, "Abortion and Fathers' Rights," in J. M. Humber and R. F. Almeder, eds., Biomedical Ethics Reviewes: Reproduction, Technology, and Rights (Totowa: Humana Press, 1996): 5-26, at 11-12; see also L. L. Owens, "Coerced Parenthood as Family Policy: Feminism, the Moral Agency of Women, and Men's 'Right to Choose," Alabama Civil Rights \& Civil Liberties Law Review 5 (2013): 1-33, at 18 ("Though he cannot choose whether or not a biologically-related fetus will be carried to term, the man should have the choice whether to actually be a parent (in the legal and social senses), even when he cannot decide whether he will become a biological parent."); M. B. Jacobs, "Intentional Parenthood's Influence: Rethinking Procreative Autonomy and Federal Paternity Establishment Policy," American University Journal of Gender, Social Policy and the Law 20, no. 3 (2012): 489-508 (questioning "why a man who has no intent or desire to be a father should be adjudicated a legal father against his will").

39. See Hiester, supra note 31, at 213 n.4.

40. S. Fairyington, "The Lonely Existence of Mel Feit, Men'sRights Advocate," The Atlantic, January 24, 2013, available at <http://www.theatlantic.com/sexes/archive/2013/01/thelonely-existence-of-mel-feit-mens-rights-advocate/267413/> (last visited April 14, 2015).

41. M. Gaynor, "The Lesson of 'Roe v. Wade for Men': Making Abortion a Right Was Wrong," RenewAmerica.com, March 10, 2006, available at <http://www.renewamerica.com/columns/gaynor/060310> (last visited April 14, 2015); see also K. Lopez, "Abortion Leads to Emotional Damage for Men, Too," The Grand Island Independent, March 25, 2006, available at <http://www.priestsforlife.org/clippings/2006/06-03-25men. htm> (last visited April 14, 2015). 
42. Planned Parenthood v. Casey, 505 U.S. 833, 927-28 (1992) (Blackmun, J., dissenting in part).

43. In the context of abortion, where prochoice advocates and the core holdings of Roe $v$. Wade and other abortion cases see the autonomy of the pregnant woman as central to the question, antiabortion advocates believe the status and attendant rights of the fetus as a person should decide the question. In pre-embryo disputes, many people would similarly grant the pre-embryos a right to life (and thus right to be implanted and developed to term), so the characterization of such disputes as expectational interest versus expectational interest is incomplete. Because none of the cases I will discuss treat preembryos as persons, however, the analysis is not altered by this caveat.

44. See Sanger, About Abortion, supra note 38, at 862.

45. Use of the term pre-embryo versus embryo is disputed. On the one hand, many courts and commentators have found the distinction helpful, often using a rubric that a pre-embryo is developed at most for fourteen days and is not yet implanted in a woman's uterus. See Davis v. Davis, 842 S.W.2d 588, 592-94 (1992); S. A. Weber, "Dismantling the Dictated Moral Code: Modifying Louisiana's In Vitro Fertilization Statutes to Protect Patients' Procreative Liberty," Loyola Law Review 51, no. 3 (2005): 549-601, at 559-560. On the other, the term preembryo has been criticized as an artificial distinction aimed at creating a moral or conceptual divide where none exists. See J. M. Zekan Makdisi, "Genetically Correct: The Political Use of Reproductive Terminology," Pepperdine Law Review 32, no. 1 (2004): 1-37, at 5-17. For specificity and ease of use, I use the term pre-embryo.

46. See A. K. Upchurch, "The Deep Freeze: A Critical Examination of the Resolution of Frozen Embryo Disputes through the Adversarial Process," Florida State University Law Review 33, no. 2 (2005): 395-435, at 399-400.

47. See Kass $v$. Kass, 696 N.E.2d 174 (N.Y. 1998).

48. Id., at 180; see also J. A. Robertson, "Precommitment Strategies for Disposition of Frozen Embryos," Emory Law Journal 50, no. 4 (2001): 989-1046, at 1006.

49. See In re Marriage of Dahl and Angle, 194 P.3d 834 (Or. App. 2008); Roman v. Roman, 193 S.W.3d 40 (Tex. App. 2006); Litowitz v. Litowitz, 48 P.3d 261 (Wash. 2002) (en banc).

50. In re Dahl and Angle, 194 P.3d at 837.

51. See In re Marriage of Witten, 672 N.W.2d 768 (Iowa 2003).

52. C. H. Coleman, "Procreative Liberty and Contemporaneous Choice: An Inalienable Rights Approach to Frozen Embryo Disputes," Minnesota Law Review 84, no. 1 (1999): 55-127, at 59.

53. See M. P. Strasser, "You Take the Embryos But I Get the House (and the Business): Recent Trends in Awards Involving Embryos Upon Divorce," Buffalo Law Review 57, no. 4 (2009): 1159-1225.

54. See In re Witten, 672 N.W.2d 768. One case from Massachusetts used the contemporaneous mutual consent approach, but only after determining that the written agreements as to disposition of the stored pre-embryos were unenforceable because the ex-husband signed blank consent forms, which his exwife filled in later stating that in the event of separation their wishes were that the pre-embryos be implanted in the wife. See A.Z. v. B.Z., 431 Mass. 150 (2000).

55. See Davis v. Davis, 1989 WL 140495 (Tenn. Cir. Ct. 1989).
56. See Davis v. Davis, 1990 WL 130807, *2 (Tenn. App. 1990). 57. Davis v. Davis, 842 S.W.2d 588, 598 (Tenn. 1992).

58. Id., at 603 .

59. Id., at 604; see also Davis, 1990 WL 130807, at n.1.

60. Davis, 842 S.W.2d at 604 .

61. Id.

62. See J.B. v. M.B., 783 A.2d 707, 711 (N.J. 2001) (quoting J.B. $v$. M.B., 331 N.J. Super. 223, 232 (2000)).

63. Id., at 720 .

64. See Reber v. Reiss, 42 A.3d 1131, 1133 (Pa. Super. 2012).

65. Id., at 1134 .

66. $I d$., at 1142

67. Szafranski v. Dunston, 993 N.E.2d 502, 503 (Ill.App. 1 Dist. 2013).

68. Id., at 505 .

69. $I d$.

70. Id., at 517-518.

71. Kass v. Kass, 696 N.E.2d 174, 179 n.4 (N.Y. 1998).

72. This is in contrast to the approach taken in other countries. For example, Israel gives significant weight to the desire to become a parent through use of frozen embryos. See. E. Waldman, "Cultural Priorities Revealed: The Development and Regulation of Assisted Reproduction in the United States and Israel," Health Matrix: Journal of Law-Medicine 16, no. 1 (2006): 65-106.

73. See I. G. Cohen, "The Right Not to be a Genetic Parent?" Southern California Law Review 81, no. 6 (2008): 1115-1196, at 1194-1195.

74. See J. L. Madeira, "Woman Scorned?: Resurrecting Infertile Women's Decision-Making Autonomy," Maryland Law Reviere 71, no. 2 (2012): 339-410.

75. One scholar who argues that courts should more strongly credit the difficulty that older unpartnered women face in becoming mothers supports her argument with data on what she terms "disappearing dads," explicitly arguing that courts should credit the emotional stake held by women because men view fatherhood as simply writing checks. See E. Waldman, "The Parent Trap: Uncovering the Myth of 'Coerced Parenthood' in Frozen Embryo Disputes," American University Law Review 53, no. 5 (2004): 1021-162.

76. Davis v. Davis, 1989 WL 140495 (Tenn. Cir. Sept. 21, 1989).

77. Davis v. Davis, 842 S.W.2d 588, 590 n4 (Tenn. 1992).

78. Reber v. Reiss, 42 A.3d at 1139.

79. See, e.g., In re A.C., 533 A.2d 611 (D.C. 1987); Jefferson v. Griffin Spaulding County Hospital Authority, 274 S.E.2d 457 (Ga. 1981).

80. See J. A. Parness, "Pregnant Dads: The Crimes and Other Misconduct of Expectant Fathers," Oregon Law Review 72, no. 4 (1993): 901-918, at 906-908; D. Johnsen, "Shared Interests: Promoting Healthy Births without Sacrificing Women's Liberty," Hastings Law Journal 43, no. 3 (1992): 569-614, at 571.

81. See M. Fernandez and E. Eckholm, "Pregnant, and Forced to Stay on Life Support," New York Times, January 7, 2014, at A1.

82. K. T. Matsumura, "Public Policing of Intimate Agreements," Yale Journal of Law Eீ Feminism 25, no. 1 (2013): 159-215, at 189 \& n.230 (quoting D. Blankenhorn, Op-Ed., "How My View on Gay Marriage Changed," New York Times, June 22, 2012, available at <http://www.nytimes.com/2012/06/23/opinion/ how-my-view-on-gay-marriage-changed.html> (last visited April 14, 2015)). 